\title{
ЮБИЛЕИ И ДАТЫ
}

УДК 58(092) + 574.3

\section{ГЛАВНОЕ ДОЛЖНО ОСТАВАТЬСЯ ГЛАВНЫМ (К 85-ЛЕТИЮ ЛЮДМИЛЫ АЛЕКСЕЕВНЫ ЖУКОВОЙ)}

\section{А.А. Нотов ${ }^{1}$, В.А. Нотов ${ }^{2,1}$, Е.В. Зубкова ${ }^{3}$, М.М. Палёнова ${ }^{4}$,} Л.В. Зуева ${ }^{1}$, С.А. Иванова ${ }^{1}$, Е.А. Андреева ${ }^{1}$

${ }^{1}$ Тверской государственный университет, Тверь ${ }^{2}$ МБОУ СОШ № 3, пос. Редкино

${ }^{3}$ Институт физико-химических и биологических проблем почвоведения РАН, Пущино

${ }^{4}$ Всероссийский научно-исследовательский институт лесоводства и механизации лесного хозяйства, Пушкино

19 февраля 2020 г. исполнилось 85 лет выдающемуся ученому, заслуженному деятелю науки Российской Федерации, доктору биологических наук, профессору Людмиле Алексеевне Жуковой. Она внесла значительный вклад в развитие отечественной биологии и экологии, популяционно-онтогенетического направления. Л.А. Жукова ведущий специалист в области популяционной ботаники, прекрасный педагог, основатель научной школы, автор фундаментальных работ.

Ключевые слова: юбилеи, творческая биография, Людмила Алексеевна Жукова популяиионная биология, популяиионно-онтогенетический подход. DOI: $10.26456 /$ vtbio144

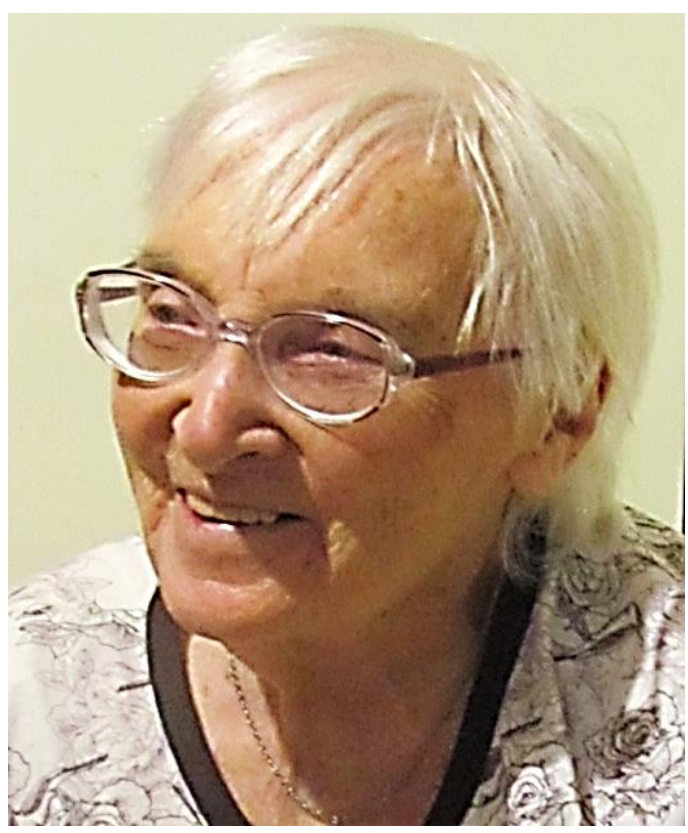


Выдающемуся ученому, заслуженному деятелю науки Российской Федерации, доктору биологических наук, профессору Людмиле Алексеевне Жуковой 19 февраля 2020 г. исполнилось 85 лет. Этот юбилей совпадает с 65-летием её научной деятельности. Людмила Алексеевна стояла у истоков становления популяционноонтогенетического направления в России и внесла значительный вклад в развитие популяционной биологии и экологии растений. Свою жизнь она посвятила развитию идей её выдающихся учителей - Алексея Александровича Уранова и Татьяны Ивановны Серебряковой основателей уникальных научных школ.

Родилась Людмила Алексеевна 19 февраля 1935 г. в Москве ${ }^{1}$. Жить вместе с родителями - Алексеем Николаевичем и Тамарой Сергеевной Жуковыми - не пришлось. Воспитывали её бабушка и дед - Екатерина Михайловна и Николай Алексеевич Жуковы. Особое отношение к растениям появились уже в раннем детстве. Первое знакомство с живой природой произошло в Томилино, где были сад, сосновый бор и речка Пехорка. Вместе с дедом она сажала и поливала цветы, с восторгом слушала увлекательные рассказы бабушки и дедушки о лесе и его жителях. В три года внучка уже стала читать и интересовалась стихами. Родные научили её любить и уважать людей, сопереживать, помогать детям и взрослым.

В шесть лет мирная жизнь была нарушена войной. Навсегда остались в памяти ужасы военного времени - бомбежки, пожары, холод и голод. Дом в Томилино был сильно повреждён после разрыва фугасных бомб, переехали в поселок Полярник под городом Раменское. Зимой 1941 г. страдали от голода и болезней, чудом удалось выжить. В 1943 г. Л.А. Жукова поступила в 43 женскую школу в районе Старого Арбата (рис. 1). В школе были прекрасные учителя. В трудные военные и послевоенные годы они согревали учеников у железных буржуек, отдавали детям последние кусочки хлеба. С первого класса школьники взяли шефство над госпиталем. Навсегда в их памяти остались стоны раненых и кровь на повязках. Наравне с взрослыми дети выносили все тяготы этого страшного времени. В этих тяжелых условиях учителя сделали все, чтобы их ученики выросли образованными людьми, достойными своей великой Родины. Особенно благодарна Людмила Алексеевна своей учительнице биологии - Марии Николаевне Микрюковой, которая разрешала ей в любое время после уроков приходить в кабинет биологии, ухаживать за цветами, ставить разные опыты.

\footnotetext{
${ }^{1}$ Более полные сведения о биографии Л.А. Жуковой даны в других публикациях (Жукова, 2006; Жукова ..., 2006; Нотов и др., 2015).
} 

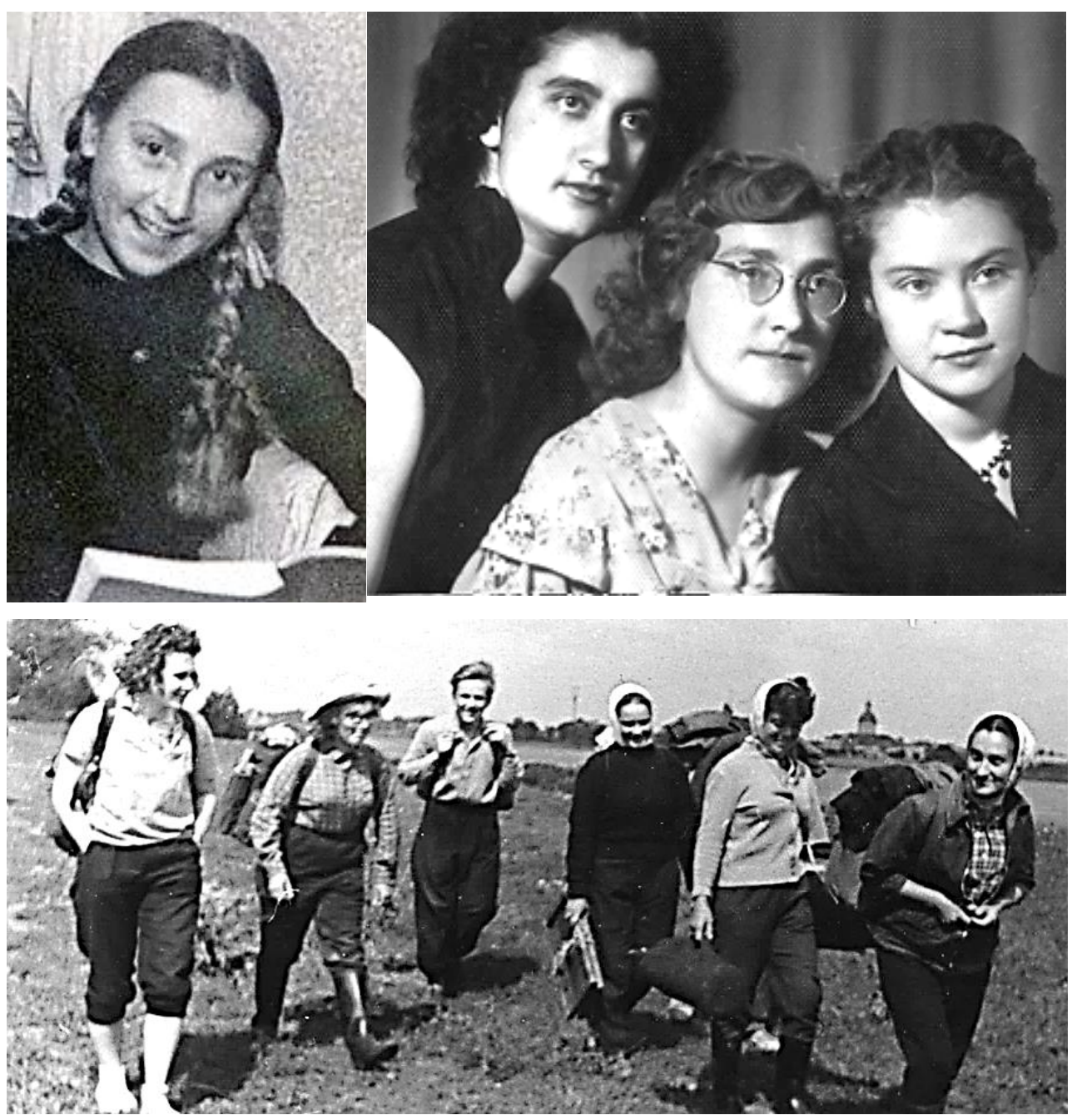

Рис. 1. Л.А. Жукова в школе и институте:

ученица 43-й московской школы (1946 г.); с подругами по институту - Е. Чахалян и

Л. Заугольновой; сбор материала для диссертации в Дединово (1961-1964 гг.)

С 7-го класса Л.А. Жукова стала ходить в туристический кружок дворца пионеров, участвовала в походах по Подмосковью, собирала гербарий. Летом 1951 г. был поход через Южную Украину в Крым, в котором школьники увидели заповедник Аскания-Нова, степи Украины, Сиваш, горный Крым, Бахчи-Сарай и Крымский заповедник. Хотя Л.А. Жуковой всегда очень нравилась литература и поэзия, но полтора месяца походной жизни помогли ей окончательно определить будущую профессию.

В 1953 г. Л.А. Жукова окончила с золотой медалью 43 школу г. Москвы. Людмила Алексеевна хотела стать, прежде всего, биологомучителем и поступила в Московский государственный педагогический 
институт им. В.И. Ленина на факультет естествознания.

Студенческие годы сыграли особую роль в раскрытии у Людмилы Алексеевны таланта исследователя и педагога. Лекции читали выдающиеся ученые, среди которых были М.С. Гиляров, Ю.Б. Филипович, Ф.Н. Правдин, С.П. Наумов, А.А. Уранов, Т.И. Серебрякова. Большое значение имел ботанический кружок, которым руководил Алексей Александрович Уранов. В работе кружка вместе с Л.А. Жуковой активно участвовали и её сокурсники (рис. 1). Они регулярно делали доклады на его заседаниях, выезжали на осенние, зимние и весенние экскурсии. Позднее Л.А. Жукова с небольшой группой студентов-кружковцев стала регулярно посещать в МГУ лекции А.А. Уранова по геоботанике, Т.А. Работнова по луговедению, С.С. Станкова по географии растений, спецкурсы на факультете естествознания МГПИ. Особенно запомнились лекции А.А. Уранова. Их посещали математики, физики, историки, литераторы. А.А. Уранов покорял любого слушателя удивительным артистизмом, потрясающей глубиной, эмоциональностью, красотой мыслей и идей. Он искренне восхищался гармонией природы, красотой и глубиной её организации, учил радоваться каждому открытию. Эти ценности стали для Людмилы Алексеевны путеводной звездой в ее научном и педагогическом творчестве. Очень многое дали полевые практики в пос. Вербилки и Павловской Слободе Московской области. Уже в студенческие годы Л.А. Жуковой были сделаны первые ботанические открытия. В 1954 г. она обнаружила новый для Приокско-Террасного заповедника вид - Orchis ustulata L., чем удивила знаменитого московского флориста П.А. Смирнова, который руководил практикой студентов. В 1956 г. Л.А. Жукова собрала в Дарвиновском заповеднике материал для курсовой работы, посвященной белоусу торчащему (Nardus stricta L.). О нём была написана и первая статья (1959). В 1957 г. начались исследования на станции пойменного луговодства на Оке около с. Дединово (рис. 1). Её руководителем в Дединово был профессор Т.А. Работнов.

Первым научным руководителем Л.А. Жуковой в МГПИ была профессор Т.И. Серебрякова. Они были очень близки по духу и гармонично сочетали научное и художественное восприятие природы. Наблюдая за развитием своей ученицы, Т.И. Серебрякова смогла почувствовать, что структурная ботаника не позволит в полной мере раскрыть её исследовательский талант. Л.А. Жукову интересовала популяционная жизнь растений, которая тогда была для ботаников ещё малопонятной. Вторым научным руководителем стал Алексей Александрович Уранов. Его идеи о дискретном описании онтогенеза растений, о фитогенных полях, сопряжённости ценопопуляций растений в фитоценозах и волновая теория развития ценопопуляций 
заложили тот уникальный фундамент, который определил весь дальнейший научный путь Л.А. Жуковой.

В 1958 г. Л.А. Жукова закончила с отличием факультет естествознания и была оставлена на кафедре. Были продолжены исследования щучки в Дединове. Одновременно начался насыщенный и богатый по своей географии период экспедиций и поездок, который помог сформировать очень широкий ботанический кругозор. Она работала в Батумском, Тбилисском и Никитском ботанических садах, собирала гербарий для кафедры, изучала растительность субтропиков.

Научная жизнь кафедры была очень многоплановой. Регулярно проводились научные семинары. В 1964 г. открылась проблемная биологическая лаборатория (ПБЛ). Её ботанический отдел возглавил профессор А.А. Уранов. Началось активное изучение онтогенеза и структуры популяций растений. Защитили кандидатские диссертации Н.И. Шорина, Л.Б. Заугольнова, О.В. Смирнова, Е.И. Курченко, Л.И. Воронцова, Н.И. Белянина, Л.М. Шафранова, Л.Е. Гацук и другие аспиранты А.А. Уранова и И.Г. Серебрякова. Людмила Алексеевна под руководством А.А. Уранова выполнила диссертационное исследование, посвящённое возрастной структуре популяций луговика дернистого (Жукова, 1967). Защита состоялась в марте 1967 г. Эта диссертация стала одной из первых работ, в которых была детально описана сложная динамика формирования онтогенетической структуры популяций дерновинных травянистых растений.

После защиты диссертации для Л.А. Жуковой начался период дальних выездных практик и экспедиций. Сложно перечислить все экспедиции и практики, в которых побывала Людмила Алексеевна (рис. 3). Всего их было более 70. Среди них поездка на Соловецкие острова с тяжёлыми переходами по 30 км в день, геоботаническими описаниями в лесах, на лугах, побережьях, сушкой гербария над костром. Были экспедиции в Закарпатье, Архангельск, Холмогоры, путешествия по Северной Двине, Мурманской области, Карелии. Л.А. Жукова проводила практики в заповеднике «Кивач», в Кандалакше, Кижах, Заонежье, в Прибайкальском заповеднике. В этих поездках был собран уникальный по объёму разноплановый материал.

В 1974 г кафедра ботаники и проблемная лаборатория МПГИ осиротели. Скончался А.А. Уранов. Заведовать кафедрой ботаники стала Т.И. Серебрякова. Несмотря на тяжелую для всех потерю, Урановская школа была достойно представлена в 1975 г. на XII Международном Ботаническом конгрессе, проходившем в Ленинграде. Организован и проведён в Таврическом дворце популяционный семинар, в котором участвовала Л.А. Жукова (рис. 2). Делегатам конгресса продемонстрирована методика выделения онтогенетических состояний, которая вызвала интерес у зарубежных учёных. По 
инициативе доктора Дж. Уайта было создано международное общество популяционной биологии. Урановская школа продолжала очень продуктивно работать. В 1970-1980-е гг. опубликовано 5 монографий о ценопопуляциях растений $(1976,1977,1987,1985$, 1988), 3 выпуска «Диагнозов и ключей возрастных состояний растений» (1980-1983), 2 методических пособия по изучению ценопопуляций и консорций $(1986,1987)$ и объёмный обзор «Тhe population structure of vegetation» (1985). Во всех отмеченных выше изданиях Людмила Алексеевна принимала активное участие. Благодаря её совместной работе с А.С. Комаровым возникает новое оригинальное направление, связанное с моделированием динамики популяций (Заугольнова и др., 1988). Создаваемые модели позволили достигнуть качественно иного уровня понимания сложных природных процессов и явлений.

Сфера научных интересов Л.А. Жуковой быстро расширялась. Она активно изучала популяции растений разных жизненных форм. В многочисленных поездках и экспедициях (рис. 3) собран уникальный фактический материал колоссальных объёмов. Он обобщен в её докторской диссертации «Динамика ценопопуляций луговых растений», которая блестяще защищена в 1988 г. Эта работа была новаторской по своей широте и глубине. В ней Людмила Алексеевна раскрыла различные аспекты популяционной жизни луговых растений и заложила основы для концепции поливариантности онтогенеза.

Учебно-методическая деятельность Л.А. Жуковой в МГПИ также была очень разноплановой (рис. 4). Она читала курсы лекций по морфологии и анатомии растений, систематике низших и высших растений, географии растений, фитоценологии, популяционной экологии, лекции для преподавателей пединститутов СССР на ФПК. Её лекции отличались высоким профессионализмом, логической завершенностью и чёткостью. Людмила Алексеевна руководила также луговой группой Проблемной биологической лаборатории и сотрудничала с различными научными учреждениями. Совместно с коллективом ПБЛ и кафедрой ботаники она постоянно участвовала в организации и проведении конференций, а также выступала с докладами на Международных и Всесоюзных конференциях.

К концу 1980 гг. Л.А. Жукова стала одним из ведущих специалистов в области популяционной экологии, педагогом очень высокого уровня. Она достойно продолжала дело своих учителей, отдавая все силы развитию популяционно-отногенетического направления, мечтала о появлении новых творческих коллективов, которые будут развивать традиции Урановской школы. В этом она видела выполнение своего профессионального и нравственного долга. 


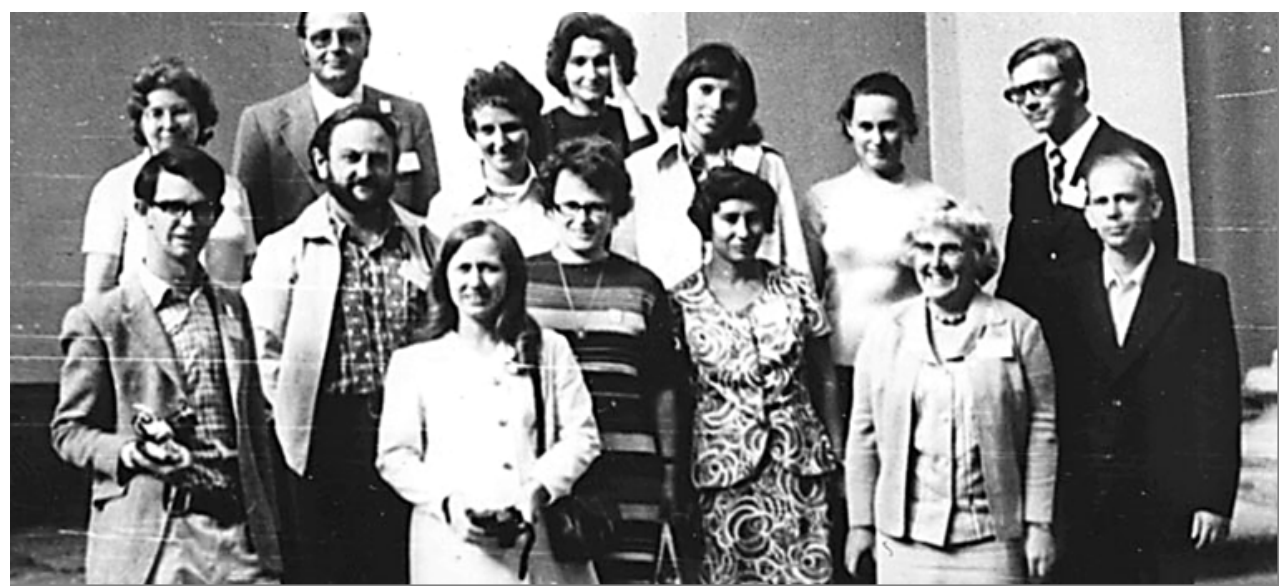

Рис. 2. Участники популяционного семинара в Таврическом дворце (1975 г.): в первом ряду крайний слева - доктор Дж. Уайт, вторая справа - Л.А. Жукова

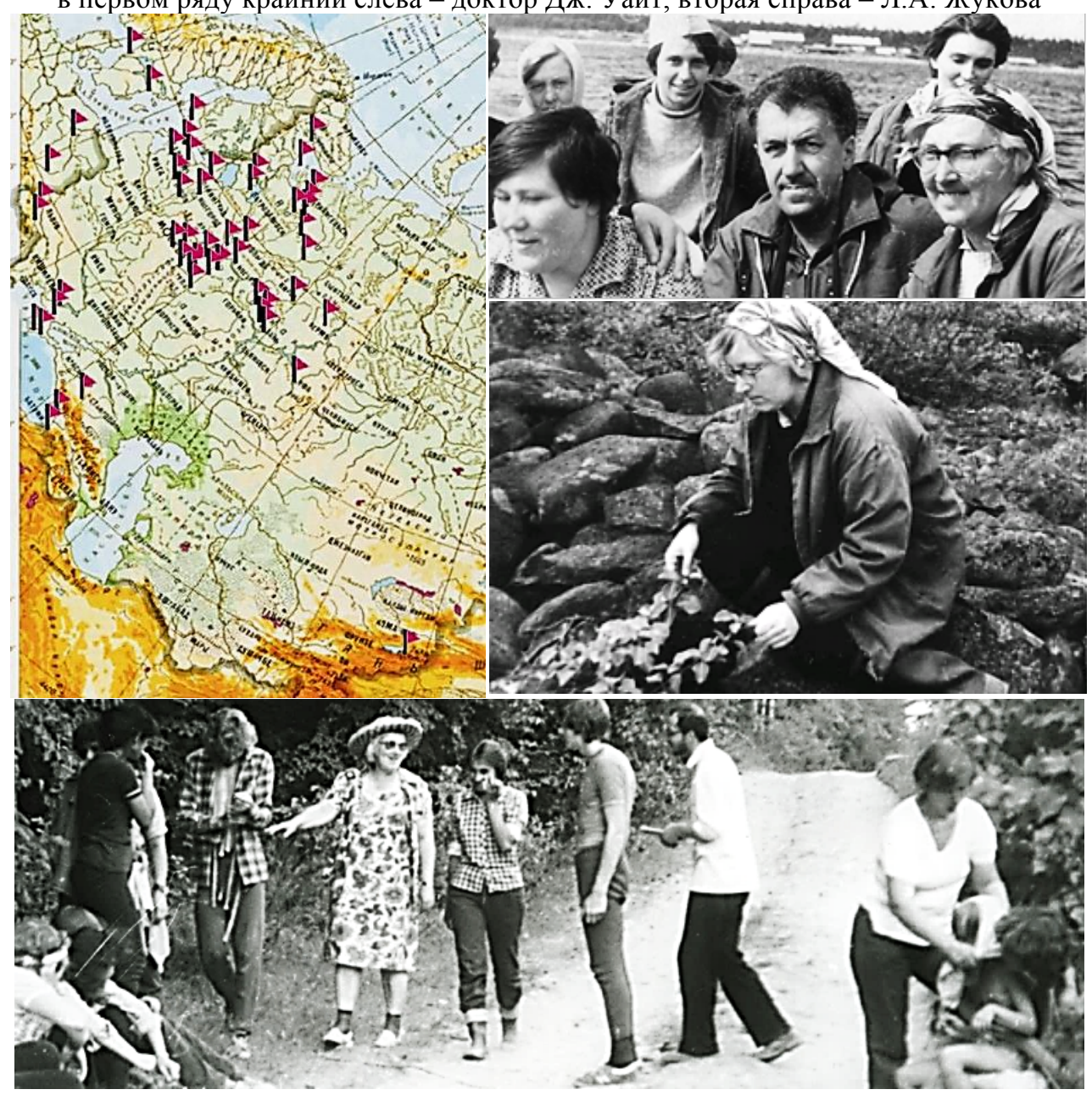

Рис. 3. Экспедиции и полевые практики Л.А. Жуковой:

Соловки (1967 г.), Карелия (1981 г.); Республика Марий Эл (1980-е гг.) 


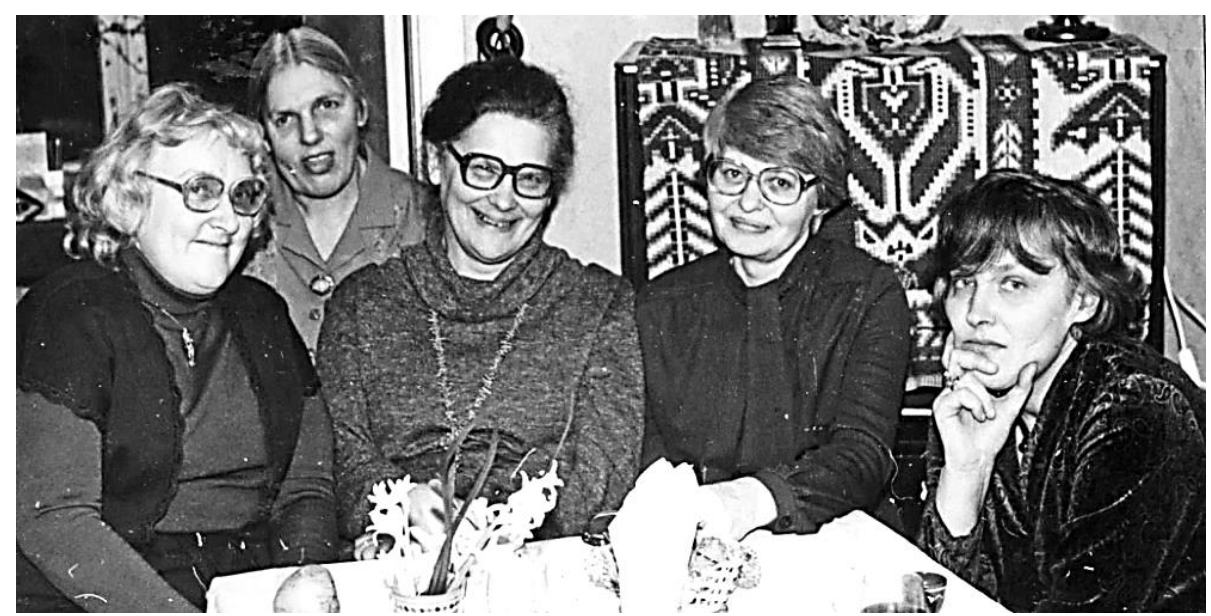

Рис. 4. Л.А. Жукова с московскими коллегами:

слева направо А.М. Былова, Т.И. Серебрякова, И.В. Плотникова, С.П. Шаталова

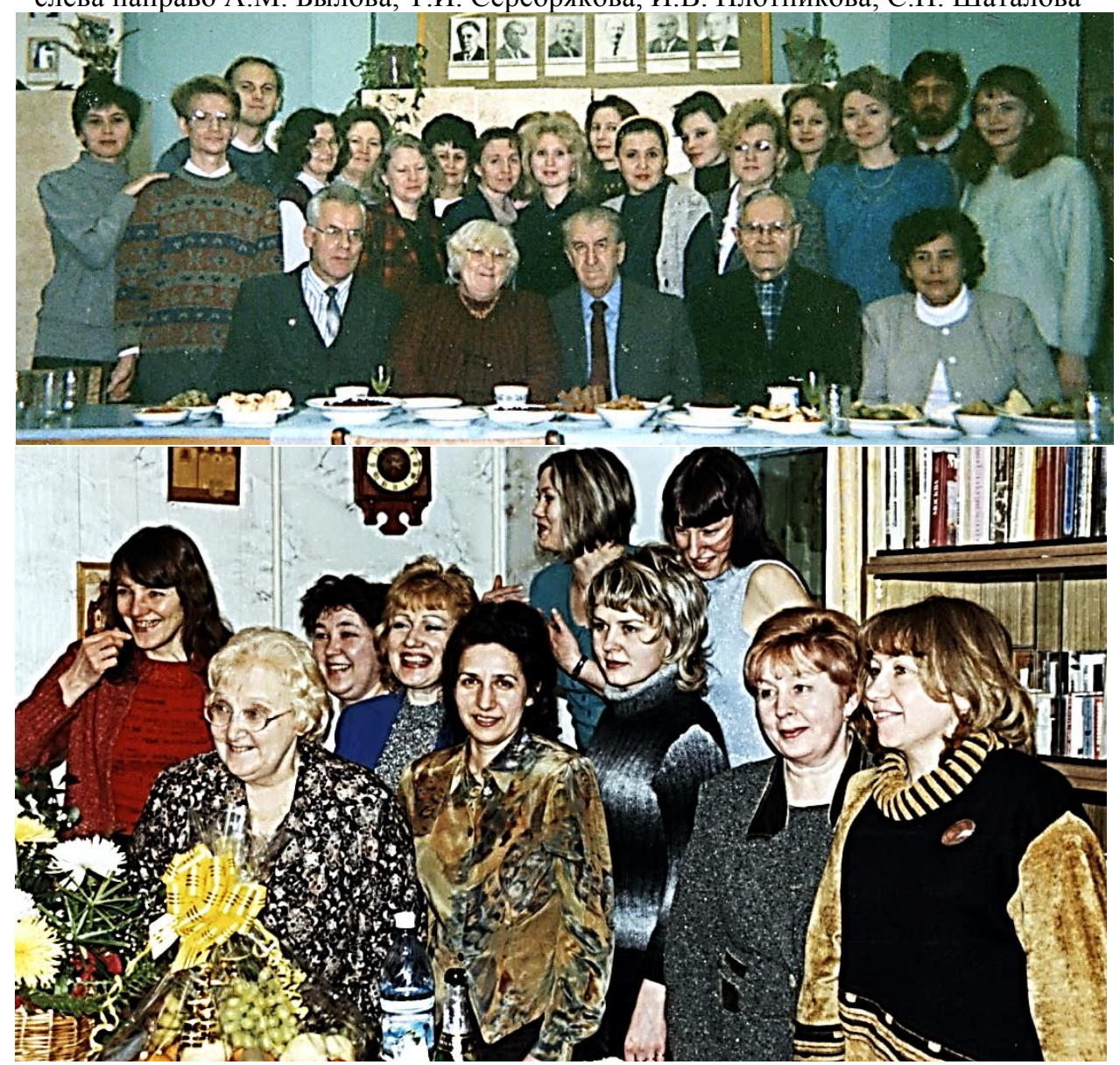

Рис. 5. Л.А. Жукова в Марийском государственном университете:

кафедра ботаники, экологии и физиологии растений на юбилее Л.И. Шабалина (1995 г.); с учениками и коллегами дома в Йошкар-Оле (2005 г.) 
Людмила Алексеевна никогда не боялась ставить перед собой невыполнимые по масштабам и сложности задачи. Неожиданно для всех в 1989 г. она приняла приглашение ректора Марийского университета профессора В.П. Ившина, и в 1990 г. стала заведовать кафедрой ботаники, экологии и физиологии растений МарГУ. Более четверти века своей жизни она посвятила развитию этого университета. Безусловно, это был подвиг во имя любимого дела. Надо обладать большим мужеством, чтобы решиться в 55 лет поехать в другую республику и с нуля начать создание кафедры, школы, традиций. Мечта о новом популяционно-онтогенетическом центре и желание сделать всё возможное для продолжения дела своих учителей оказались сильнее, чем понимание степени риска. Этот период в жизни Л.А. Жуковой был крайне сложным, но невероятно продуктивным. Он стал успешным во многом благодаря поддержке и помощи её мужа Льва Александровича Исаева (рис. 3, 5).

В Йошкар-Олу Л.А. Жукова привезла свою научную библиотеку, уникальную гербарную коллекцию, которая стала основой для единственного в мире онтогенетического гербария. На кафедре она создала атмосферу взаимопонимания и сотрудничества, принимала очень близкое участие в жизни коллег и студентов, всегда была в курсе проблем нового для нее города и республики. Все это требовало огромных сил и целеустремленности, организаторского таланта. Стояло много сложных задач. Людмила Алексеевна реализовала оригинальную рейтинговую систему, развивающую творческий потенциал студентов. Опубликованы авторские учебно-методические пособия.

В 1991 г. открыта аспирантура. Стали защищаться диссертации, написанные под руководством Л.А. Жуковой. Научная деятельность была очень разноплановой. Впервые осуществлён синтез онтогенетических и физиологических исследований. Проведено масштабное изучение онтогенезов лекарственных растений. Стали регулярно издаваться «Онтогенетические атласы», которые пока не имеет аналогов в мировой науке. Людмила Алексеевна была организатором многочисленных семинаров и научных конференций. В их числе три Всероссийских популяционных семинара и шесть Всероссийских, а позднее с международным участием, конференций «Принципы и способы сохранения биоразнообразия».

Л.А. Жукова руководила 25 грантами, финансируемыми Министерством образования РФ, Головным Советом по биологии при Комитете по высшей школе, Госкомвузом РФ, РФФИ. Один грант был международным. Внешнее финансирование существенно укрепило позиции кафедры, позволило создать Онтогенетический гербарий и Популяционно-онтогенетический музей, которые не имеют мировых 
аналогов. Сейчас научная часть гербария включает более 6300 гербарных листов и 350 рисунков (Жукова и др., 2016б).

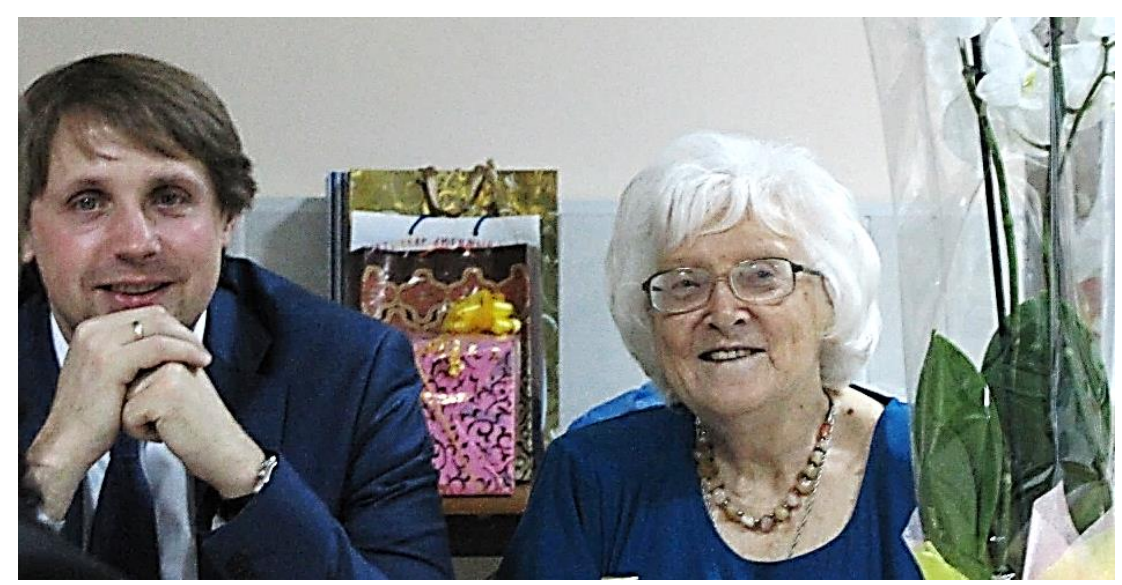

Рис. 6. Л.А. Жукова с ректором МарГУ М.Н. Швецовым на вечере, посвящённом её 80-летию (2015 г.)

Рейтинг кафедры и университета с приходом Людмилы Алексеевны стал расти быстрыми темпами. Благодаря её титанической работе МарГУ стал одним из ведущих научных центров в области популяционной биологии растений. На его базе проводились стажировки научных сотрудников и преподавателей. Людмила Алексеевна была членом разных диссертационных советов. Под её руководством выполнено и защищено 3 докторских и 21 кандидатская диссертация, подготовлено 3 доктора и 15 кандидатов биологических наук для Республики Марий Эл, 10 из них в настоящее время работают в МарГУ. Популяционно-онтогенетическая школа профессора Л.А. Жуковой официально зарегистрирована в Российской академии наук. Людмила Алексеевна стала академиком МАНЭБ и НьюЙоркской академии наук, была государственным научным стипендиатом РАН, Соросовским стипендиатом, награждена Почетной грамотой Министерства Просвещения СССР и ЦК профсоюзов, нагрудным знаком «Почетный работник высшего профессионального образования». В 2003 г. ей присуждено звание «Заслуженный деятель науки Российской Федерации», а в 2005 г. - звание «Почетный профессор МарГУ». В 2015 г. работа Людмилы Алексеевны отмечена благодарностью президента Республики Марий Эл. В честь её 80летнего юбилея и 25-летия развития популяционно-онтогенетического направления в МарГУ проведена очень масштабная и значимая VI конференция «Принципы и способы сохранения биоразнообразия», которая была наиболее (Леонидов, 2015) (рис. 6).

Творческая биография Людмилы Алексеевна связана практически со всеми этапами формирования популяционно- 
онтогенетического подхода в России и включает очень много значимых и ярких событий. География её экспедиций и результаты проведенных научных исследований практически необозримы, а число студентов, аспирантов, учёных, которые учились у Л.А. Жуковой, сосчитать просто невозможно. Со всеми она щедро делилась своими знаниями, идеями, заряжала творческой энергией и оптимизмом. Все её успехи и достижения - результат огромной, титанической работы, объем которой нам просто невозможно представить. К сожалению, не удалось ей избежать тяжелых потрясений, потерь, проблем со здоровьем. Основные этапы своей биографии Людмила Алексеевна описала в замечательном очерке «Мир принадлежит оптимистам ...» (Жукова, 2006). Он позволяет почувствовать глубину её внутреннего мира, его тонкую организацию, понять жизненные принципы и ценности. Однако Людмила Алексеевна неисчерпаема и многогранна, и даже самый подробный обзор не раскроет все стороны её души и результаты многоплановой научной и педагогической деятельности.

Вклад Л.А. Жуковой в науку грандиозен. Она автор более 500 работ, среди которых более 20 авторских и коллективных монографий и 25 учебно-методических и справочных изданий. В них уникальные фактические материалы, оригинальные подходы и идеи, ценные научные концепции. Л.А. Жукова смогла существенно дополнить и развить концепцию дискретного описания онтогенеза А.А. Уранова. Лично Людмилой Алексеевной и вместе с её учениками детально описано более 60 онтогенезов растений разных жизненных форм. Среди них не только сосудистые растения. Заложены основы периодизации онтогенеза лишайников (Суетина и др., 1997). Полученные данные позволяют сейчас моделировать онтогенез представителей многих групп жизненных форм.

Большое методологическое значение имеет разработанная Л.А. Жуковой концепция поливариантности развития биосистем разного уровня (включая организмы, популяции, сообщества). Она является наиболее значимым теоретическим обобщением, которое позволило достигнуть качественно иного уровня понимания принципов организации живых систем и биологических процессов. Предложены оригинальные классификации поливариантности онтогенеза и биоценозов (Жукова, 2012; Жукова, Зубкова, 2017; Жукова, Нотов, $2018,2019 б)$. Актуально развитие этой концепции на зоологическом материале и включение её в общую теорию жизни. Представления о поливариантности должны стать основой биоморфологических, популяционных и фитоценотических исследований. Совместно с профессором А.С. Комаровым разработаны имитационные модели поливариантности темпов развития травянистых растений (Жукова, Комаров, 1990, 1991; Зубкова и др., 2016). 


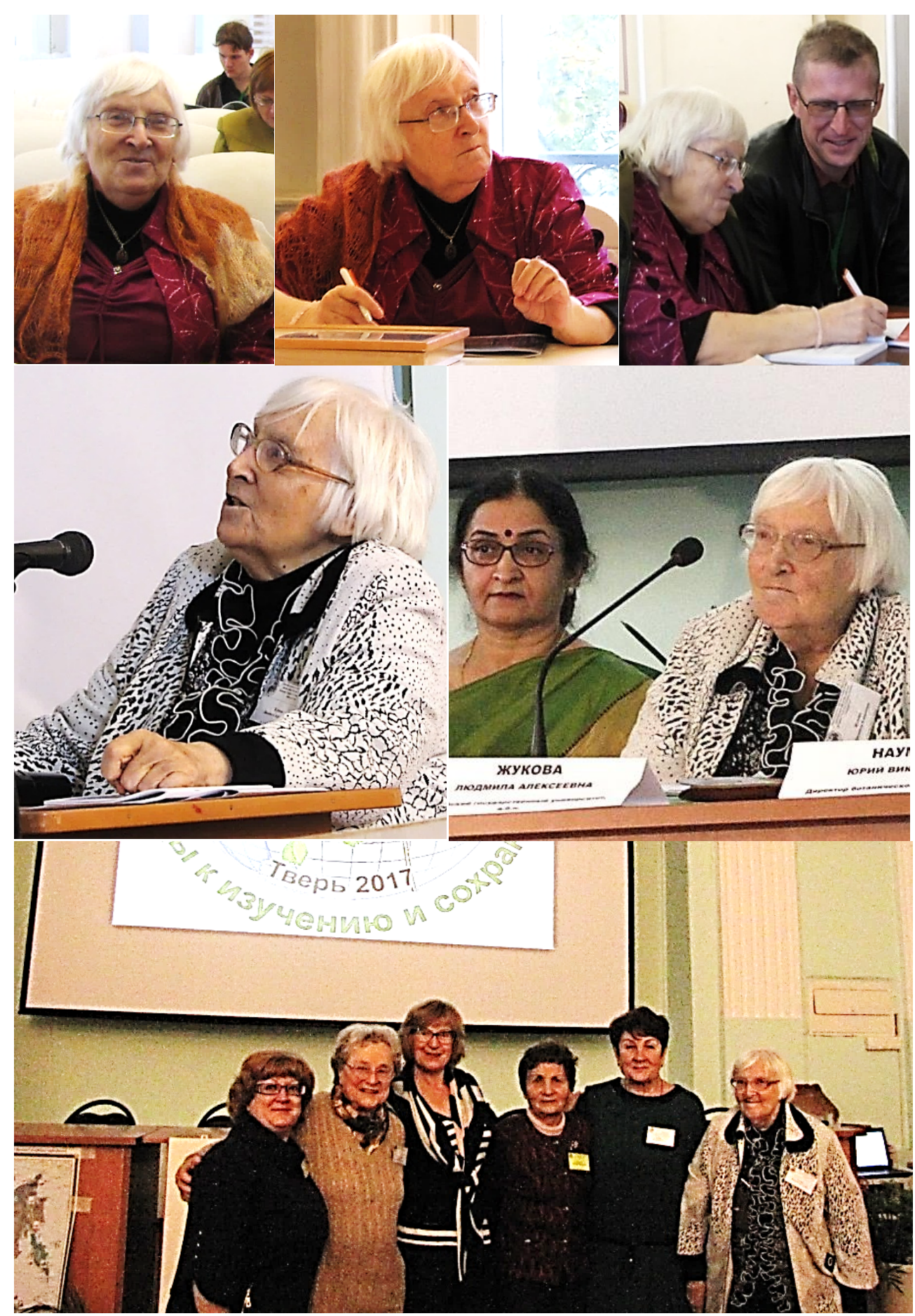

Рис. 6. На международных конференциях:

V геоботаническая школа-конференция (Санкт-Петербург, 2015 г.); конференция, посвященная 100-летию кафедры ботаники ТвГУ (Тверь, 2017 г.) 
Людмила Алексеевна внесла весомый вклад в разработку многих теоретических проблем биологии и фитоценологии. Среди них систематизация разнообразия циклов воспроизведения растений и грибов, классификация типов онтогенеза семенных растений, нормальных ценопопуляций, теория сопряженности и концепция фитогенных полей (Жукова, 1967, 1983, 1985, 1995, 2012). Подходы к изучению структуры и динамики ценопопуляций дополнены новыми оригинальными методиками, которые позволяют количественно оценивать процессы самоподдержания численности и перспектив развития ценопопуляций, сопряжённость, размеры и мощность фитогенных полей (Жукова и др., 1976, 2006; Жукова, 1985, 1988, 1995, 2000, 2012).

В своих работах и докладах Людмила Алексеевна неоднократно подчёркивала значимость проблемы сопряженного анализа разных компонентов экосистем (Жукова, Нотов, 2015б, 2019 и др.). Она стала инициатором специальных исследований, посвященных сопряженному анализу онтогенеза дерева и процессов формирования консорции. Предложенный подход позволил соотнести этапы формирования эпифитного покрова и динамику морфологической и анатомической дифференциации разных онтогенетических состояний дерева (Notov, Zhukova, 2015). Такой анализ важен при изучении закономерностей внутренней организации лесных сообществ.

Людмила Алексеевна совместно со своими коллегами провела большую работу по уточнению характеристик в экологических шкалах Д.Н. Цыганова и методике работы с диапазонными шкалами (Экологические ..., 2010). Обоснованы понятия экологической валентности и толерантности, подходы к анализу экологического разнообразия при решении различных задач в фитоценологии, флористике, в области рационального использования ресурсов и охраны природы (Dorogova et al., 2016b и др.).

Собранные и проанализированные Л.А. Жуковой материалы стали основой для создания электронных баз геоботанических описаний луговых и лесных фитоценозов. Эти базы использованы при организации экологического мониторинга в национальном парке «Марий Чодра» и в государственном заповеднике «Большая Кокшага» (Жукова, Палёнова, 2015б и др.).

Даже этот далеко неполный перечень разрабатываемых Людмилой Алексеевной проблем и вопросов позволяет оценить широту её научных интересов и разноплановость полученных результатов. Она делает всё возможное для дальнейшего развития не только популяционной биологии, но других дисциплин, сопряжённых с этим направлением. Многие интересующие её темы уже вышли за рамки популяционно-онтогенетического подхода, но крайне важны 
для экологии и биологии в целом. Практически каждая проблема связана с дальнейшими комплексными исследованиями. Это точки роста новых научных направлений. Широчайший научный кругозор позволяет Л.А. Жуковой хорошо их видеть и чувствовать. В статье, посвящённой анализу роли популяционно-онтогенетического подхода в современной биологии и экологии, обобщены представления о возможностях его применения, определены области синтеза знаний (Нотов, Жукова, 2013). Обоснована необходимость использования этого подхода при решении практических проблем сохранения биоразнообразия. Блестящие доклады Л.А. Жуковой на конференциях разного уровня способствовали привлечению внимания специалистом к этим важным векторам дальнейшего развития науки (рис. 6).

Благодаря удивительной целеустремлённости, одержимости, преданности любимому делу и бережному отношению к традициям Урановской школы Людмила Алексеевна смогла очень многое сделать в науке и образовании. Её 80-летний юбилей и VI конференция «Принципы и способы сохранения биоразнообразия» в МарГУ потрясли многих (Леонидов, 2015; Нотов и др., 2015). Фантастическое для одного человека число научных публикаций, учеников, докладов, идей, новая научная школа, перечислить всё просто невозможно. Редко кому в жизни удаётся даже и сотой доли этого достигнуть. Но, к сожалению, и цена была слишком велика. Проблемы со здоровьем у Людмилы Алексеевны начались ещё в детстве, но после многолетнего запредельного по напряжению ритма жизни и работы справляться с болезнями стало крайне сложно. И было совершенно непонятно, где искать силы и что делать. Вероятно, многие на её месте остановились бы гораздо раньше этого рубежа, чтобы сберечь себя от большой беды. Но, к сожалению, для Людмилы Алексеевны это было невозможно. Она не представляет свою жизнь без науки, без обожаемых растений, без общения с коллегами, без докладов на конференциях, без ежедневной работы. И важно не просто всё это иметь, а отдавать любимому делу всю себя без остатка. Независимо от воли и сознания выбор «главного» при осмыслении одного из любимых ею мудрых изречений «главное должно оставаться главным» всегда происходит в пользу науки и творческой работы. Для Людмилы Алексеевны подругому просто не может быть. Так она организована. По-видимому, в этом и заключается секрет её вечного двигателя, который помогает не останавливаться, даже если реальная ситуация уже не позволяет сохранять прежние темпы.

В преддверии очередного 85-летнего юбилея Людмила Алексеевна опять смогла всех удивить результатами, которые получены за прошедшие пять лет. Несмотря на тяжёлые болезни и эмоциональные потрясения за эти годы написано и издано около 
полусотни работ. Среди них два объёмных справочных издания, учебное пособие, 7 очень важных в методическом отношении статей, три из которых на английском языке (Жукова и др., 2015a, б, 2016г; Notov, Zhukova, 2015, 2019; Жукова, Зубкова, 2016; Dorogova et al., 2016b; Популяционно-онтогенетическое..., 2018; Жукова, Нотов, 2018; Нотов, Жукова, 2019a; Notov, Zhukova, 2019). Подготовлены и опубликованы разноплановые материалы для 15 конференций. На 5 из них было очное участие с пленарными докладами (рис. 6). Однако эти, безусловно, впечатляющие цифры вряд ли могут дать представление о значимости итогов за прошедшие пять лет. Каждая работа весома, затронут широкий спектр тем, связанных с перспективами развития популяционно-онтогенетического направления, биологии и экологии в целом. Что же сделала Людмила Алексеевна за этот период, какие задачи решала и над какими проблемами работала?

Относясь с большой любовью и трепетом к своим учителям и научному направлению, которому она посвятила всю свою жизнь, Людмила Алексеевна совершила почти невозможное, чтобы сохранить для будущих поколений исследователей всё, что связано с истоками и развитием Урановской школы. Два справочных издания, которые были завершены и изданы только благодаря её одержимости и титанической работе, уникальны по своему содержанию и детальности. В первом собраны все материалы об основателях отечественных научных школ - А.А. Уранове, Т.А. Работнове, И.Г. Серебрякове, Т.И. Серебряковой, (Жукова и др., 2015б). Во втором издании, объёмом более 400 страниц, упорядочена разноплановая информация о специалистах в области популяционной экологии и популяционно-онтогенетическом музее МарГУ (Популяционно-онтогенетическое..., 2018). Эти обобщающие труды гармонично дополняют прекрасные статьи и материалы, посвящённые учителям, близким друзьям и коллегам Л.А. Жуковой. Они написаны очень живо, искренне, с большой любовью и глубоким уважением. Всё это помогает не только в полной мере оценить их научный вклад, но и ощутить специфику внутреннего мира, осмыслить этапы творческой биографии. В числе таких работ статьи о Т.И. Серебряковой и А.А. Уранове (Жукова, 2015а, г, 2017б; Жукова, Шивцова, 2016), А.С. Комарове (Жукова и др., 2016в, г; Зубкова и др., 2016), Л.Н. Дорохиной (Жукова и др., 2015в), И.М. Ермаковой (Жукова и др., 2016а). Безвременный уход из жизни А.С. Комарова был большим потрясением для Людмилы Алексеевны, и она сделала всё возможное для сохранения о нём светлой памяти и продолжения начатых вместе с ним работ. К сожалению, многие его идеи и планы остались нереализованными. Тяжёлой потерей для Л.А. Жуковой стала и кончина Л.Н. Дорохиной. 


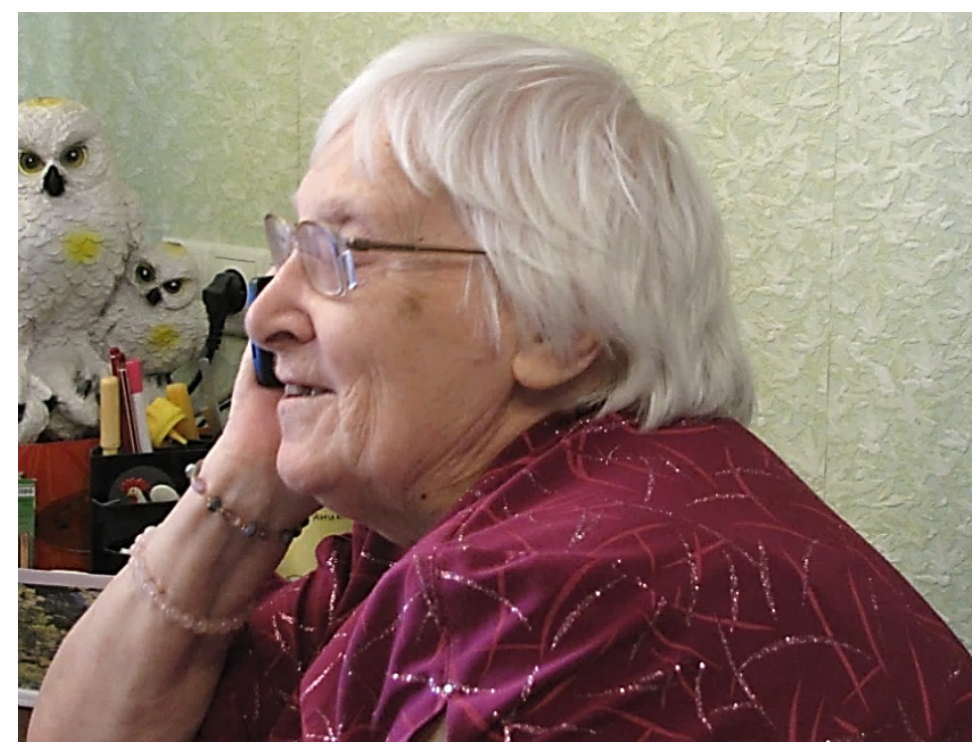

Рис. 7. Общение с коллегами по телефону (2019 г.)

Особой благодарности заслуживает подготовка к публикации и издание сборника стихотворений Т.И. Серебряковой «Оранжевые блики» (см. Жукова, 2017б). Благодаря такому очень бережному и трепетному отношению Людмилы Алексеевны к творческому наследию своего любимого учителя, многие поколения будущих ботаников смогут почувствовать удивительно тонкую организацию внутреннего мира Татьяны Ивановны. И ещё один бесценный подарок для нас сделала Людмила Алексеевна. Преодолев излишнюю требовательность в оценке результатов собственного поэтического творчества, она наконец-то решилась опубликовать сборник своих стихотворений «Подари мне, солнышко, ласки и тепла» (Жукова, 2017a). Теперь эти очень искренние и проникновенные стихи стали доступны всем, кому интересен её глубокий и тонкий взгляд на окружающий мир.

Людмила Алексеевна не оставляет без внимания ничего, что может помочь укрепить позиции популяционной экологии. После выхода в свет монографии Ю.А. Злобина с соавторами, в которой даны основы мониторинга ценопопуляций редких растений, она опубликовала очень содержательную рецензию (Жукова, 2015в). Л.А. Жукова сильно обеспокоена судьбой уникального популяционноонтогенетического музея и онтогенетического гербария МарГУ. На всех уровнях и в различных публикациях она регулярно обращает внимание на особую значимость этих коллекционных фондов для дальнейшего развития популяционных исследований (Козырева и др., 2015; Жукова и др., 2016б; Osmanova et al., 2016). 
Можно только удивляться тому, как виртуозно удаётся Людмиле Алексеевне одновременно решать сразу много задач. По каждому найденному в ходе многолетних поисков перспективному направлению исследований за прошедшие пять лет ею опубликованы важные обобщающие статьи, которые существенно развивают прежние результаты. Даже краткий обзор содержания этих статей потребует написания отдельной объёмной работы. Мы ограничимся лишь перечнем основных проблем и итогов, который важен для понимания широты научных интересов Л.А. Жуковой. Выявлены актуальные аспекты сопряжённого анализа компонентов экосистем (Жукова, Нотов, 2015б; Нотов, Жукова, 2015; Notov, Zhukova, 2015). Разработаны методические основы сопряжённого анализа онтогенеза дерева и процесса формирования эпифитного покрова с учётом динамики структурной дифференциации ствола и кроны (Notov, Zhukova, 2015). Раскрыты возможности использования диапазонных шкал в геоботанических и флористических исследованиях (Жукова, 2015б; Dorogova et al., 2016b; Жукова и др., 2017a; Дорогова и др., 2019). Оценена роль популяционно-онтогенетического подхода в геоботанике, флористике и практической деятельности по сохранению биоразнообразия (Жукова, Нотов, 2015а; Жукова, Палёнова, 2015а, б; Жукова, Зубкова, 2016, 2017; Жукова и др., 2017б). Выявлены стратегические направления развития экологического образования и воспитания (Жукова, 2016; Dorogova et al., 2016а; Зубкова и др., 2017; Жукова, Нотов В., 2019).

Особый интерес Людмила Алексеевна проявляет сейчас к разработке концепции поливариантности и оценке её роли в развитии разных научных дисциплин (Жукова и др., 2015а; Жукова, Зубкова, 2016; Нотов, Жукова, 2016, 2017, 2019а, б; Жукова, Нотов, 2017а-в, 2018, 2019; Notov, Zhukova, 2019). Рассмотрены особенности развития концепции применительно к биоценозам (Жукова, Нотов, 2018, 2019), основные направления её использования при изучении жизненных форм и в эволюционной морфологии растений (Жукова, Нотов, 2017в; Нотов, Жукова, 2019а, б). Концепции поливариантности посвящены статьи, над которыми работает Л.А. Жукова в настоящее время.

Людмила Алексеевна как никто другой понимает, что для развития любой замечательной идеи необходимо живое общение с коллегами. Мы преклоняемся перед её мужеством и решительностью, которые вопреки всем запретам врачей, позволили нам слушать великолепные доклады Л.А. Жуковой на конференциях в Йошкар-Оле (2015), Санкт-Петербурге (2015), Кирове (2017), Твери (2017), Пущино $(2016,2017)$ (рис. 6). Каждый, кто был на конференциях, на которые приезжала Людмила Алексеевна, знает, что одним выступлением её участие не ограничивается (Нотов и др., 2015). Обязательно будет 
несколько докладов, активное обсуждение на круглых столах, общение с коллегами, консультации, и многое другое. Это усиливает глубину содержания и целостность каждого мероприятия, его динамичность и придаёт особую эмоциональную окраску.

Сердечную благодарность мы выражаем Людмиле Алексеевне за международную научную конференцию «Биоразнообразие: подходы к изучению и сохранению», которая была посвящена 100летию кафедры ботаники ТвГУ (Тверь, 8-11 ноября 2017 г.). Плодотворное сотрудничество с Тверским университетом началось в 2012 г., когда Л.А. Жукова приехала в Тверь на конференцию в честь 95-летнего юбилея кафедры ботаники (Нотов и др., 2015). В 2017 г., как и прежде, Людмила Алексеевна вошла в состав оргкомитета и активно участвовала в подготовке конференции, разработке её программы. Её поддержку и помощь мы ощущали на всех этапах. Людмила Алексеевна привезла в Тверь замечательную выставку фотографий Л.А. Исаева, подарившую всем участникам конференции большой эмоциональный заряд. Её великолепный пленарный доклад (рис. 6), рассказ и демонстрация презентации о Татьяне Ивановне Серебряковой, интенсивная работа на всех заседаниях помогли нам создать атмосферу свободного и искреннего общения. Каждая деталь способствовала укреплению тёплой дружественной обстановки. С большим трепетом кафедра ботаники хранит сейчас оригинальный подарок от Людмилы Алексеевны - столетник-алоэ. Очень запомнилась работа по подготовке статей для «Вестника ТвГУ» по материалам пленарных докладов (Нотов, Жукова, 2018).

Сложно всё учесть, а тем более оценить в полной мере. И как бы ни было горько за тот формализм в оценках, к которому мы сейчас пришли, но любой современный чиновник, учитывающий только «показатели» за последние пять лет, подтвердил бы весомость результатов. Однако в данном случае за каждой работой и докладом яркая идея, крайне важный для дальнейшего развития анализ, итоги глубокого осмысления колоссального материала и титаническое напряжение. И никакие болезни, и потрясения не могут помешать Людмиле Алексеевне думать о научных проблемах, о будущем науки. Как же необходимо для сохранения наших уникальных научных школ и традиций, чтобы ещё для кого-то наука стала и оставалась тем «главным», которое помогает сейчас Людмиле Алексеевне делать «невозможное». Тогда это «главное» будет дарить искреннюю радость (рис. 6,7$)$ даже в крайне сложных ситуациях.

Людмила Алексеевна - замечательный человек, который излучает необыкновенное тепло и свет. Она неиссякаемый источник оптимизма и новых идей. Мы искренне желаем ей доброго здоровья, сил, творческого вдохновения и благополучия! 


\section{Список основных работ Л.А. Жуковой ${ }^{2}$}

Авторефераты, монографии, сборники научных трудов

Жукова Л.А. 1967. Изменение возрастного состава популяций луговика дернистого на Окских лугах: автореф. дис. ... канд. биол. наук. М. 19 с.

Жукова Л.А. 1988. Динамика ценопопуляций луговых растений: автореф. дис. ... д-ра биол. наук. Новосибирск. 32 с.

Жукова Л.А. 1995. Популяционная жизнь луговых растений. Йошкар-Ола. 225 с.

Ценопопуляциии растений: основные понятия и структура 1976. М.: Наука. 216 с.

Ценопопуляции растений: развитие и взаимоотношения 1977. М.: Наука. 134 с.

Динамика иенопопулящий 1985. М.: Наука. 206 с.

The population structure of vegetation. Handbook of vegetation 1985. Dodrecht etc.666 p.

Заугольнова Л.Б., Жукова Л.А., Смирнова О.В., Комаров А.С. 1988. Ценопопуляции растений (очерки популяционной биологии). М.: Наука. 92 с.

Онтогенетический атлас лекарственных растений 1997-2004 / отв. ред. Л.А. Жукова. Йошкар-Ола: МарГУ. Т. 1. 239 с. Т. 2. 2000. 267 с. Т. 3. 2002. 279 с. T. 4. 2004. 239 c.

Онтогенетический атлас растений 2007-2013 / отв. ред. Л.А. Жукова. Т. 5-7. Йошкар-Ола: МарГУ. Т. 5. 2007. 240 с. Т. 6. 2011.336 с. Т. 7. 2013. 362 с.

Материаль Всероссийского популяциионного семинара 1998-2002 / отв. ред. Л.А. Жукова и др. I-V. Йошкар-Ола, Казань. І. 1998. 332 с. II. Ч. 1. 305 с. Ч. 2. 272 c. III. 2001.236 c. IV. 2001. 236 c. V. 2002. Ч. 1. 274 c. Ч. 2.260 c.

Восточноевропейские леса: история в голоцене и современность 2004 / отв. ред. О.В. Смирнова. Кн. 1. М.: Наука. 479 с.

Принципь и способы сохранения биоразнообразия 2004-2015 / отв. ред. Л.А. Жукова: материалы Всерос. науч. конф. I-IV. Йошкар-Ола: МарГУ. I. 2004. 292 c. II. 2006. 404 c. III. 2008. 674 c. IV. 2010. 462 c. V. 2013. T. 1. 213 c. T. 2. 312 c. V. 2013. T. 2. 312 c. VI. 2015.415 c.

Поливариантность развития организмов, популящий и сообществ 2006 / отв. ред. Л.А. Жукова. Йошкар-Ола: МарГУ. 326 с.

Экологические шкаль и методы анализа экологического разнообразия растений 2010 / Л.А. Жукова и др.; общ. ред. Л.А. Жукова. Йошкар-Ола: МарГУ. 368 с.

Учебно-методические и справочные издания

Диагнозы и ключи возрастных состояний луговых растений 1980-1983. М.: МГПИ. Ч. 1. 1980.80 с. Ч. 2. 1983.96 с. Ч. 3. 1983.78 с.

Биологический энциклопедический словарь. 1986. М.: Советская энциклопедия.

Изучение структуры и взаимоотношений цеенопопуляций. 1986. М.: МГПИ. 77 с.

Заугольнова Л.Б., Ермакова И.М., Жукова Л.А. 1987. Подходы к изучению популяций и консорций. М.: МГПИ. 78 с.

Жукова Л.А., Ведерникова О.П., Смирнова О.В., Торопова Н.А., Евстигнеев О.И. 1994. Популяционная экология растений. Йошкар-Ола. 28 с.

Диагнозы и ключи возрастных состояний злаков 1997. М.: Прометей. 141 с.

Шестакова Э.В., Жукова Л.А., Ведерникова О.П., Османова Г.О. 2000. Высшие растения. Анатомия и морфология. Йошкар-Ола. 58 с.

Полевой экологический практикум 2000 / ред. Л.А. Жукова. Йошкар-Ола. Ч. 1. 102 с.

2 Приведён список всех работ за 2015-2019 гг., более полная библиография других трудов дана в публикациях о Л.А. Жуковой и в базе данных ИСТИНА (Заугольнова и др., 1996; Жукова ..., 2006, 2011-2018; Нотов и др., 2015). 
Биоэкология 2005 /ред. О.Л.Воскресенская, Л.А.Жукова. Йошкар-Ола:МарГУ. 252 с. Османова Г.О., Ведерникова О.П., Жукова Л.А. 2006. Водоросли и грибы: учеб. пособие. Йошкар-Ола. 204 с.

Ведерникова О.П., Османова Г.О., Жукова Л.А. 2010. Высшие растения. Анатомия и морфология: учеб. пособие. Йошкар-Ола: МарГУ. 160 с.

Османова Г.О., Ведерникова О.П., Жукова Л.А. 2011. Биоразнообразие: учеб. практика. Йошкар-Ола: МарГУ. 163 с.

Жукова Л.А., Ведерникова О.П., Быченко Т.М., Османова Г.О. $2015 \mathrm{a}$. Лекарственные растения. Разнообразие жизненных форм: учеб. пособие для студентов и школьников. Йошкар-Ола: МарГУ. 167с.

Жукова Л.А., Шафранова Л.М., Онипченко В.Г., Зубкова Е.В. 2015б. Выдающиеся популяционные экологи и биоморфологи - А.А. Уранов, Т.А. Работнов, И.Г. Серебряков, Т.И. Серебрякова: CD-ROM-диск. Йошкар-Ола.

Жукова Л.А. 2017а. Подари мне, солнышко, ласки и тепла. Тверь: ТвГУ. 82 с.

Популяционно-онтогенетическое направление в России и ближнем зарубежье 2018 / отв. ред. Л.А. Жукова; сост. Л.А. Жукова, Н.М. Державина, И.В. Шивцова: справочное издание. Тверь: ТвГУ. 440 с.

Cmambu

Жукова Л.А. 1973. Возрастной состав популяций луговика дернистого на пойменных пастбищах Северной Двины и Оки // Биол. науки. № 7. С. 67-72.

Жукова Л.А. 1974. Белоус торчащий // Биологическая флора Московской области. Т. 1. М.: МГУ. С. 6-20.

Жукова Л.А. 1976. Луговик дернистый // Биологическая флора Московской области. М.: МГУ. Т. 3. С. 62-75.

Жукова Л.А., Уранов А.А., Ермакова И.М., Григорьева Н.М., Егорова В.Н., Матвеев А.P., Сугоркина Н.С. 1976. Новые аспекты в изучении сопряженности луговых растений // Структура и динамика растительного покрова. М.: Наука. С. 119-120.

Уранов А.А., Григорьева Н.М., Егорова В.Н., Ермакова И.М., Жукова Л.А., Курченко Е.И., Матвеев А.Р. 1976. О популяционном подходе к изучению и использованию лугов // Биол. науки. № 5. С. 74-85.

Жукова Л.А. 1979. Большой жизненный цикл луговика извилистого и структура его ценопопуляций // Бот. журн. Т. 64. № 4. С. 525-540.

Жукова Л.А. 1980. Луговик извилистый // Биологическая флора Московской области. Т. 5. М. С. 46-57.

Gatuk L.E., Smirnova O.V., Vorontzova L.I., Zaugolnova L.B., Zhukova L.A. 1980. Age states of plants of various growth forms a review // J. Ecol. V. 68. № 2. P. 675-696 c.

Жукова Л.А. 1981. Влияние антропогенных факторов на возрастной состав ценопопуляций луговика дернистого в различных географических условиях // Бюл. МОИП. Отд. биол. Т. 86. Вып.1. С. 87-99.

Жукова Л.А. 1983. Род Подорожник // Биологическая флора Московской области. Вып. 7. М. С. 188-209.

Жукова Л.А. 1983. Онтогенезы и циклы воспроизведения растений // Журн. общ. биологии. Т. 44. № 3. С. 361-374.

Zhukova L.A., Ermakova I.M. 1985. Structure and dynamics of coenopopulation of some temperate grasses // The population structure of vegetation. Handbook of vegetation. Dodrecht, Boston, Lancaster. P. 170-205.

Жукова Л.А. 1986. Поливариантность луговых растений // Жизненные формы в экологии и систематике растений. М.: МГПИ им. Ленина. С. 104-114.

Жукова Л.А. 1988. Некоторые аспекты изучения онтогенеза семенных растений // 
Вопросы онтогенеза растений. Йошкар-Ола: МарГУ. С. 3-23.

Жукова Л.А., Заугольнова Л.Б., Мичурин В.Г., Онипченко В.Г., Торопова Н.А., Чистякова А.A. 1989. Программа и методические подходы популяционного мониторинга у растений // Биол. науки. № 12. С. 65-75.

Заугольнова Л.Б., Бологова В.П., Ермакова И.М., Жукова Л.А., Матвеев А.Р., Сугоркина Н.С. 1989. Популяционные аспекты структуры и динамики луговых агроценозов // Биол. науки. № 11. С. 31-48.

Жукова Л.А., Комаров А.С. 1990. Поливариантность онтогенеза и динамика ценопопуляций растений // Журн. общ. биологии. Т. 51. №4.С.450-461.

Жукова Л.А., Комаров А.С. 1991. Количественный анализ динамической поливариантности в ценопопуляциях подорожника большого при разной плотности посадок // Биол. науки. № 8. С. 51-66.

Жукова Л.А., Ведерникова О.П., Файзуллина С.Я., Балахонов С.В., Максименко O.E., Глотов Н.B. 1996. Эколого-демографическая характеристика природных популяций Plantago major L. // Экология. № 6. С. 445-453.

Суетина Ю.Г., Жукова Л.А., Санникова Н.А. 1997. Онтогенез ксантории настенной (Xanthoria parietina (L.) Th.Fr.) // Онтогенетический атлас лекарственных растений. Т. 1. Йошкар-Ола: МарГУ. С. 210-214.

Скочилова Е.А., Пигулевская Т.К., Жукова Л.А. 2000. Морфологическая и физиологическая оценка онтогенеза Chelidonium majus L. // Бот. журн. T. 85. № 10. C. $55-61$

Жукова Л.А. 2001. Многообразие путей онтогенеза в популяциях растений // Экология. № 3. С. 169-176.

Жукова Л.А. 2001. Популяционно-онтогенетическое направление в России // Бюл. МОИП. Отд. биол. 2001. Т. 106. Вып. 5. С. 17-24.

Жукова Л.А., Глотов Н.В. 2001. Морфологическая поливариантность онтогенеза в природных популяциях растений // Онтогенез. № 6. С. 455-461.

Михайлова Н.В., Михайлов А.В., Богданова Н.Е., Комаров А.С., Жукова Л.А. 2008. Имитационная модель инвазионной динамики популяций неморальных видов трав на неоднородной территории // Бюл. МОИП. Т. 113. Вып. 5. С. 68-75.

Шивиова И.В., Жукова Л.А. 2009. Новый подход к изучению пространственной структуры вегетативно-подвижных видов на примере земляники лесной (Fragaria vesca L.) // Вестн. Томск. гос. ун-та. № 323. С. 370-373.

Жукова Л.А. 2010. Поливариантность жизненных форм Х. Раункиера // Биологические типы Х. Раункиера и современная ботаника: мат-лы Всерос. науч. конф. Киров: ВятГГУ. С. 203-209.

Жукова Л.А. 2012. Значение биоморфологии для популяционно-онтогенетических исследований // Актуальные проблемы современной биоморфологии. Киров: Радуга-Пресс. Разд. 1.2.6. С. 91-105.

Жукова Л.А. 2012. Концепция фитогенных полей и современные аспекты их изучения // Изв. Самар. науч. центра РАН. Т. 14. №1(6). С. 1462-1465.

Жукова Л.А., Османова Г.О., Шивиова И.В., Ведерникова О.П. 2012. Популяционно-онтогенетическая школа Марийского государственного университета и её роль в изучении биоразнообразия // Вестн. ТвГУ. Сер. Биология и экология. Вып. 16. С. 107-124.

Жукова Л.А., Нотов А.А., Турмухаметова Н.В., Тетерин И.С. 2013. Онтогенез сосны обыкновенной (Pinus sylvestris L.) // Онтогенетический атлас растений. T. VII. Йошкар-Ола. С. 26-65.

Жукова Л.А., Полянская Т.А. 2013. О некоторых подходах к прогнозированию перспектив развития ценопопуляций растений // Вестн. ТвГУ. Сер. Биология 
и экология. Вып. 31. С. 160-171.

Нотов А.А., Жукова Л.А. 2013. О роли популяционно-онтогенетического подхода в развитии современной биологии и экологии // Вестн. ТвГУ. Сер. Биология и экология. Вып. 32. № 31. С. 293-330.

Жукова Л.А. 2015а. Алексей Александрович Уранов - вице-президент Всесоюзного ботанического общества // История ботаники в России (к 100летнему юбилею РБО). Т. 1. Тольятти: Кассандра. С. 99-104.

Жукова Л.А. 2015б. Диапазонные шкалы как способ определения потенциальных и реализуемых экологических ареалов видов и экосистем // V Всерос. геобот. школа-конф. с междунар. участием (Санкт-Петербург, 4-9 окт. 2015 г.). С. 69.

Жукова Л.А. 2015в. Злобин Ю.А., Скляр В.Г., Клименко А.А. Популяции редких видов растений: теоретические основы и методика изучения. Сумы: Унив.кн., 2013. 439 с. // Вестн. ТвГУ. Сер. Биология и экология. 2015. № 4. С. 264-268.

Жукова Л.А. 2015г. Татьяна Ивановна Серебрякова - выдающийся биоморфолог $\mathrm{XX}$ столетия // Самарская Лука: Проблемы региональной и глобальной экологии. Т. 24. Вып. 3. С. 213-226.

Жукова Л.А., Нотов А.А. 2015а. Популяционные аспекты региональных флористических и геоботанических исследований // История ботаники в России (к 100-летнему юбилею РБО). Т. 3. Тольятти: Кассандра. С. 67-71.

Жукова Л.А., Нотов А.А. 2015б. Проблема сопряженного анализа разных компонентов экосистем // Принципы и способы сохранения биоразнообразия: мат-лы VI Всерос. науч. конф. с междунар. участием. Йошкар-Ола. С. 17-19.

Жукова Л.А., Палёнова М.М. 2015а. Международные конвенции сохранения биоразнообразия и популяционно-онтогенетические подходы российских учёных // Научные исследования в национальном парке «Марий Чодра». Вып. 4. Красногорский. С. 5-10.

Жукова Л.А., Палёнова М.М. 2015б. Приложение // Научные исследования в национальном парке «Марий Чодра». Вып. 4. Красногорский. С. 117-129.

Жукова Л.А., Сотникова С.М., Зубкова Е.В., Черниховский М.Е. 2015в. Людмила Николаевна Дорохина (к 75-летию со дня рождения) // Вестн. ТвГУ. Сер. Биология и экология. № 4. С. 253-263.

Зубкова Е.В., Комаров А.С., Фролов П.В., Жукова Л.А. 2015. Использование данных об онтогенезе растений для моделирования динамики популяций растений разных жизненных форм // Принципы и способы сохранения биоразнообразия: мат-лы VI Всерос. конф. с междунар. участием. ЙошкарОла. С. 159-161.

Козырева С.В., Османова Г.О., Жукова Л.А., Ведерникова О.П. 2015. Коллекция онтогенетического гербария в популяционно-онтогенетическом музее // Ботанические коллекции - национальное достояние России: Сб. науч. статей Bсерос. конф. с междунар. участием, посвящ. 120-летию Гербария им. И.И. Спрыгина и 100-летию РБО. Пенза: ПГУ. С. 242-247.

Нотов А.А., Жукова Л.А. 2015. Сопряженный анализ онтогенеза дерева и процесса формирования консорции как подход к изучению организации лесных фитоценозов // V Всерос. геобот. школа-конф. с междунар. участием (СанктПетербург, 4-9 окт. 2015 г.). С. 115.

Notov A.A., Zhukova L.A. 2015. Epiphytic lichens and bryophytes at different ontogenetic stages of Pinus sylvestris // Wulfenia. V. 22. P. 245-260.

Жукова Л.А. 2016. Экологическое образование детей старшего дошкольного возраста // Интеллектуальный потенциал XXI века: ступени познания. № 33. C. 27-31. 
Жукова Л.А., Зубкова Е.В. 2016. Демографический подход, принципы выделения онтогенетических состояний и жизненности, поливариантность развития растений // Вестн. ТвГУ. Сер. Биология и экология. № 4. С. 169-183.

Жукова Л.А., Зубкова Е.В., Сугоркина Н.С., Дорохина Л.Н. 2016а. Инна Михайловна Ермакова (к 80-летию со дня рождения) // Вестн. ТвГУ. Сер. Биология и экология. № 2. С. 125-136.

Жукова Л.А., Козырева С.В., Зубкова Е.В., Османова Г.О., Ведерникова О.П. $2016 б$. Популяционно-онтогенетический музей Марийского госуниверситета // Russian Journal of Ecosystem Ecology. T. 1. № 4. C. 18-31.

Жукова Л.А., Нотов А.А., Фролов П.В., Зубкова Е.В. 2016в. Роль А.С. Комарова в развитии популяционно-онтогенетического направления // Научные чтения по экологическому моделированию: [электрон. ресурс]. Режим доступа: http://ecomodelling.ru/new/doc/conferences/chteniya2016_programm.pdf.

Жукова Л.А., Нотов А.А., Зубкова Е.В., Паленова М.М. 2016г. Роль А.С. Комарова в развитии популяционно-онтогенетического направления // Вестн. ТвГУ. Сер. Биология и экология. № 4. С. 279-328.

Жукова Л.А., Шивцова И.В. 2016. Роль А.А. Уранова в становлении популяционно-онтогенетического направления в России и Зарубежье // Современные концепции экологии биосистем и их роль в решении проблем сохранения природы и природопользования: мат-лы VI Bсерос. (с междунар. участием) науч. школы-конф., посвящ. 115-летию со дня рождения А.А. Уранова (Пенза, 10-14 мая 2016 г.). Пенза: ПГУ. С. 7-10.

Зубкова Е.В., Жукова Л.А., Фролов П.В., Шанин В.Н. 2016. Работы А.С. Комарова по клеточно-автоматному моделированию популяционно-онтогенетических процессов у растений // Компьютерные исследования и моделирование. Т. 8. № 2. C. 285-295.

Нотов А.А., Жукова Л.А. 2016. Поливариантность развития биосистем: основные задачи и направления исследований // Современные концепции экологии биосистем и их роль в решении проблем сохранения природы и природопользования: мат-лы Всерос. (с междунар. участием) науч. школыконф., посвящ. 115-летию со дня рождения А.А. Уранова (Пенза, 10-14 мая 2016 г.). Пенза: ПГУ. С. 148-150.

Dorogova Y.A., Notov A.A., Polevshchikov M.M., Dementyeva S.M., Palagina N.I., Blinova M.L., Zhukova L.A. 2016a. The popularization of the healthy lifestyle among the students // The Social Science. V. 11. Iss. 8. P. 1929-1933.

Dorogova Y.A., Zhukova L.A., Turmuhametova N.V., Polyanskaya T.A, Notov A.A., Dementyeva S.M. 2016b. Methods of analysis of environmental diversity of plants // Biology and Medicine. V. 8. Iss. 7. Art. 354. P. 1-8.

Osmanova G.O., Kozyreva S.V., Vedernikova O.P., Zhukova L.A., Zakamskaya E.S., Skochilova E.A. 2016. The role of ontogenetic herbarium in studying intrapopulation biodiversity // Pakistan J. Botany. V. 48. № 4. P. 1495-1500.

Жукова Л.А. 2017б. Предисловие. Татьяна Ивановна Серебрякова - выдающийся биоморфолог XX столетия // Серебрякова Т.И. Оранжевые блики. Тверь: ТвГУ. С. 3-18.

Жукова Л.А., Дорогова Ю.А., Турмухаметова Н.В. 2017а. Оценка экологического разнообразия лесных экосистем с использованием экологических шкал // Сохранение лесных экосистем: проблемы и пути их решения: мат-лы Всерос. науч.-практ. конф. (Киров, 15-19 мая 2017). Киров: Радуга-Пресс. С. 154-158.

Жукова Л.А., Зубкова Е.В. 2017. Критерии выделения онтогенетических состояний и жизненности у трав и кустарничков // Биоморфологические исследования 
на современном этапе: мат-лы науч. конф. с междунар. участием (Владивосток, 3-9 окт. 2017 г.). Владивосток: Мор. гос. ун-т. С. 70-72.

Жукова Л.А., Нотов А.А. 2017а. Использование концепции поливариантности при моделировании биосистем // Математическое моделирование в экологии: Мат-лы Пятой нац. науч. конф. с междунар. участием. Пущино. С. 78-81.

Жукова Л.А., Нотов А.А. 2017б. Концепция поливариантности развития биосистем и подходы к изучению и сохранению биоразнообразия // Биоразнообразие: подходы к изучению и сохранению: мат-лы междунар. конф., посвящ. 100летию каф. ботаники ТвГУ (Тверь, 8-11 нояб. 2017). Тверь: ТвГУ. С. 104-107.

Жукова Л.А., Нотов А.А. 2017в. О некоторых направлениях изучения поливариантности биоморф // Биоморфологические исследования на современном этапе: мат-лы науч. конф. с междунар. участием (Владивосток, 3-9 окт. 2017 г.). Владивосток: Мор. гос. ун-т. С. 73-74.

Жукова Л.А., Нотов А.А., Паленова М.М. 2017б. Популяционно-онтогенетические исследования и проблема сохранения лесных экосистем // Сохранение лесных экосистем: проблемы и пути их решения: Мат-лы Всерос. науч.-практ. конф. (Киров, 15-19 мая 2017 г.). Киров: Радуга-Пресс. С. 221-226.

Зубкова Е.В., Фролов П.В., Жукова Л.А. 2017. Возможности использования компьютерных программ при обучении студентов (на примере программы CAMPUS) // Актуальные проблемы ботаники и охраны природы: мат-лы Междунар. науч.-практ. конф., посвящ. 150-летию со дня рождения Г.Ф. Морозова (Симферополь, 27-30 нояб. 2017). Симферополь. 2017. С. 331-336.

Нотов А.А., Жукова Л.А. 2017. Концепция поливариантности онтогенеза и проблемы эволюции морфологического разнообразия // Морфогенез в индивидуальном и историческом развитии: онтогенез и формирование биологического разнообразия (Москва, 22-24 нояб. 2017). М.: ПИН. С. 47-48.

Жукова Л.А., Нотов А.А. 2018. Организация биоценозов с позиции представлений о поливариантности // Вестн. ТвГУ. Сер. Биология и экология. № 3. С. 178-193.

Жукова Л.А., Нотов А.А. 2019. Моделирование сопряженной динамики ценопопуляций как метод анализа поливариантности биоценозов // Математическое моделирование в экологии (ЭкоМатМод-2019): мат-лы Шестой нац. науч. конф. с междунар. участием. Пущино. С. 79-80.

Жукова Л.А., Нотов В.А. 2019. Экологизация сознания и проблема устойчивого развития биосферы // Принципы и способы сохранения биоразнообразия: матлы VII Междунар. науч. конф. Йошкар-Ола: Вертола. С. 343-345.

Дорогова Ю.А., Турмухаметова Н.В., Жукова Л.А. 2019. Использование экологических шкал для анализа экологического разнообразия лесных экосистем // Принципы и способы сохранения биоразнообразия: мат-лы VII Междунар. науч. конф. Йошкар-Ола: Вертола. С. 259-263.

Нотов А.А., Жукова Л.А. 2019а. Концепция поливариантности онтогенеза и современная эволюционная морфология // Изв. РАН. Сер. биол. 2019. № 1. C. 52-61.

Нотов А.А., Жукова Л.А. 2019б. Поливариантность онтогенеза как источник информации о структурной эволюции растений // Мат-лы Х Междунар. конф. по экол. морфологии растений, посвящ. памяти И.Г. и Т.И. Серебряковых (Москва, 27-30 нояб. 2019 г.). Т. 2. М.: МПГУ. С. 173-178.

Notov A.A., Zhukova L.A. 2019. The concept of ontogenesis polyvariance and modern evolutionary morphology // Biology Bulletin. 2019. V. 46. № 1. P. 52-61. 


\title{
Публикации и материалы о Л.А. Жуковой
}

Заугольнова Л.Б., Дорохина Л.Н., Глотов Н.В., Файзуллина С.Я., Ведерникова О.П., Пигулевская Т.К., Балахонов С.В., Суетина Ю.Г. 1996. Людмила Алексеевна Жукова // Бюл. МОИП. Отд. биол. Т. 101. Вып. 4. С. 93-99.

Жукова Людмила Алексеевна: библиографический указатель. 2006. Йошкар-Ола. 72 с. (Материалы к библиографии ученых МарГУ; Вып. 6).

Жукова Л.А. 2006. Мир принадлежит оптимистам // Поливариантность развития организмов, популяций и сообществ. Йошкар-Ола. С. 229-278.

Леонидов М. 2015. Главное должно оставаться главным // МК в Марий Эл. 18-25 марта. С. 13.

Нотов А.А., Дементьева С.М., Иванова С.А., Зуева Л.В., Андреева Е.А. 2015. Мир спасут оптимисты (к юбилею Людмилы Алексеевны Жуковой) // Вестн. ТвГУ. Сер. Биология и экология. № 4. С. 224-252.

Жукова Людмила Алексеевна 2011-2018 // ИСТИНА: Интеллектуальная Система Тематического Исследования НАукометрических данных / НИИ механики МГУ; Лаборатория 404: [электрон. ресурс]. URL: https://istina.msu.ru/profile/pinus/ (дата обращения: 10.02.2020).

\section{THE MOST IMPORTANT MUST REMAIN THE MAIN (ON THE 85 ${ }^{\mathrm{TH}}$ ANNIVERSARY OF LYUDMILA ALEKSEEVNA ZHUKOVA)}

\author{
A.A. Notov ${ }^{1}$, V.A. Notov ${ }^{2,1}$, E.V. Zubkova ${ }^{3}$, M.M. Palenova ${ }^{4}$, \\ L.V. Zueva ${ }^{1}$, S.A. Ivanova ${ }^{1}$, E.A. Andreeva ${ }^{1}$ \\ ${ }^{1}$ Tver State University, Tver \\ ${ }^{2}$ Secondary School № 3, Redkino Settlement, Tver Region \\ ${ }^{3}$ Institute of Physicochemical and Biological Problems in Soil Science of the \\ Russian Academy of Sciences, Pushchino \\ ${ }^{4}$ All-Russian Research Institute of Silviculture and Mechanization of Forestry, \\ Pushkino
}

February $19^{\text {th }}, 2020$ marks the $85^{\text {th }}$ anniversary of outstanding scientist, Honored Scientist of the Russian Federation, Habilitated Doctor in Biology, Prof. Lyudmila Alekseevna Zhukova. She made a signification contribution to the development of the Russian biology and ecology as well as population-ontogenetic direction. L.A. Zhukova is a leading expert in the population botany, excellent teacher and lecturer, founder of the scientific school, and the author of fundamental scientific works.

Keywords: anniversaries, biography, Lyudmila Alekseevna Zhukova, population biology, population-ontogenetic approach. 


\section{Об авторах:}

НОТОВ Александр Александрович - доктор биологических наук, профессор кафедры ботаники, ФГБОУ ВО «Тверской государственный университет», 170100, Тверь, ул. Желябова, д. 33, e-mail: anotov@mail.ru.

НОТОВ Валерий Александрович - кандидат биологических наук, учитель биологии МБОУ СОШ № 3 пос. Редкино, доцент кафедры ботаники, ФГБОУ ВО «Тверской государственный университет», 171260, Тверская обл., Конаковский p-н, пгт. Редкино, Диева, д. 33a, e-mail: vnotov123@mail.ru

ЗУБКОВА Елена Владимировна - кандидат биологических наук, старший научный сотрудник лаборатории моделирования экосистем, ФГБУН Институт физико-химических и биологических проблем почвоведения РАН, 142290, Московская обл., Пущино, ул. Институтская, 2, e-mail: elenazubkova2011@yandex.ru.

ПАЛЁНОВА Мария Михайловна - кандидат биологических наук, заведующий отделом, ФБУ «Всероссийский научно-исследовательский институт лесоводства и механизации лесного хозяйства» (ФБУ ВНИИЛМ), 141202, Московская обл., Пушкино, ул. Институтская, д. 15, e-mail: palenova@gmail.com.

ЗУЕВА Людмила Викторовна - кандидат биологических наук, доцент кафедры ботаники, ФГБОУ ВО «Тверской государственный университет», 170100, Тверь, ул. Желябова, д. 33, e-mail: zuevabio2012@yandex.ru.

ИВАНОВА Светлана Алексеевна - кандидат биологических наук, доцент кафедры ботаники, ФГБОУ ВО «Тверской государственный университет», 170100, Тверь, ул. Желябова, д. 33, e-mail: dmitrievas@mail.ru

АНДРЕЕВА Елена Александровна - кандидат биологических наук, доцент кафедры ботаники, ФГБОУ ВО «Тверской государственный университет», 170100, Тверь, ул. Желябова, д. 33, e-mail: el-an72@yandex.ru.

Нотов А.А. Главное должно оставаться главным (к 85-летию Людмилы Алексеевны Жуковой) / А.А. Нотов, В.А. Нотов, Е.В. Зубкова, М.М. Палёнова, Л.В. Зуева, С.А. Иванова, Е.А. Андреева // Вестн. ТвГУ. Сер.: Биология и экология. 2020. № 1(57). C. 223-248. 